\title{
Spawning and early nursery areas of anchoveta Engraulis ringens Jenyns, 1842 in fjords of southern Chile
}

\author{
Zonas de desove y crianza larval temprana de la anchoveta Engraulis ringens Jenyns, 1842 en \\ fiordos del sur de Chile
}

\section{Claudia A. Bustos ${ }^{1}$, Mauricio F. Landaeta ${ }^{1}$ and Fernando Balbontín ${ }^{2}$}
${ }^{1}$ CIEN Austral, Centro de Investigación en Nutrición, Tecnología de Alimentos y Sustentabilidad, Universidad Austral de Chile, Campus Puerto Montt, Av. Los Pinos s/n Balneario Pelluco, Casilla 1327 Puerto Montt, Región de Los Lagos, Chile
${ }^{2}$ Facultad de Ciencias del Mar y Recursos Naturales, Universidad de Valparaíso, Valparaíso, Chile P.O. Box 5080, Reñaca, Viña del Mar, Chile
claudiabustos@uach.cl

\begin{abstract}
Resumen.- La anchoveta, Engraulis ringens, ha mostrado fluctuaciones en su abundancia y distribución a escala interdecadal a lo largo del Pacífico Sur. Sin embargo, la variabilidad espacial y temporal reciente de los eventos reproductivos es desconocida en su distribución geográfica más austral. Por ello, se analizó la variabilidad espacial y temporal del desove de E. ringens en la región de los fiordos del sur de Chile, entre 1995 y 2005. El ictioplancton recolectado con redes Bongo en el mar interior de Chile austral entre $42^{\circ} \mathrm{S}$ y $47^{\circ} \mathrm{S}$ mostró un incremento en la abundancia promedio de huevos desde 38 huevos por $10 \mathrm{~m}^{2}$ durante octubre de 1995 hasta $>14.000$ huevos por $10 \mathrm{~m}^{2}$ durante noviembre de 2005. Además, al comparar nuestros resultados con información previamente publicada de tamaño de huevos de anchoveta a lo largo de la costa chilena (Llanos-Rivera \& Castro 2004), los huevos recolectados durante noviembre de 2005 fueron más largos, anchos y con mayor volumen que los huevos de anchoveta recolectados frente al norte y centro de Chile. Durante noviembre de 2005, el desove de la anchoveta se localizó principalmente dentro de fiordos (estuario Reloncaví y fiordo Comau); la abundancia de huevos y larvas en preflexión notocordal (i.e., $<9 \mathrm{~mm}$ ) fue mayor $(>5.000$ huevos por $10 \mathrm{~m}^{2}$; hasta 2.178 larvas por $10 \mathrm{~m}^{2}$, respectivamente) comparado con las aguas someras frente a la isla de Chiloé ( $<100$ huevos por $10 \mathrm{~m}^{2}$; hasta 65 larvas por $10 \mathrm{~m}^{2}$ ). Además, se recolectaron larvas en postflexión (i.e., $>9 \mathrm{~mm}$ ) exclusivamente dentro de fiordos (10-505 larvas por $\left.10 \mathrm{~m}^{2}\right)$. La frecuencia de Brunt-Väisälä $\left(\mathrm{N}^{2}\right)$ se correlacionó positivamente en forma significativa con la abundancia de huevos y larvas de anchoveta; esto significa que las mayores abundancias de huevos y larvas fueron obtenidas en áreas con columnas de agua más estables. La estabilidad de la columna de agua podría estar relacionada con una mayor tasa de supervivencia de los estados tempranos de anchoveta y podría estar relacionada con el reciente incremento en el desembarco de otros peces pelágicos pequeños como la sardina fueguina (Sprattus fuegensis).
\end{abstract}

Palabras clave: Ictioplancton, estratificación, mar interior

\begin{abstract}
The anchoveta, Engraulis ringens, has shown fluctuations of their abundance and distribution at interdecadal scale along the South Pacific. However, the recent spatial and temporal variability of the reproductive events are unknown in their southernmost geographic distribution. Therefore, the spatial and temporal variability in the spawning of E. ringens in the fjord region of southern Chile between 1995 and 2005 was analysed. The ichthyoplankton samples collected in the inland sea of southern Chile between $42^{\circ} \mathrm{S}$ and $47^{\circ} \mathrm{S}$ during 1995-2005 with Bongo nets showed an increase in the mean abundance of anchoveta eggs, varying from mean values of 38 eggs per $10 \mathrm{~m}^{2}$ during October 1995 to $>14,000$ eggs per $10 \mathrm{~m}^{2}$ during November 2005. Moreover, comparing our data with previously published information on anchoveta egg size along Chile (Llanos-Rivera \& Castro 2004), the eggs collected during November 2005 in the inland sea were larger, wider and with higher volume than eggs collected from northern and central Chile. In the inland sea during November 2005, the anchoveta spawning was located mainly inside deep fjords (Comau and Reloncavi fjords); in such deep fjords abundance of both, eggs and preflexion larvae (i.e., $<9 \mathrm{~mm}$ ) were higher $(>5,000$ eggs per $10 \mathrm{~m}^{2}$; up to 2,178 larvae per $10 \mathrm{~m}^{2}$, respectively) than at shallow waters of Chiloe Island ( $<100$ eggs per $10 \mathrm{~m}^{2}$; up to 65 larvae per $10 \mathrm{~m}^{2}$ ). Additionally, postflexion larvae (i.e., $>9 \mathrm{~mm}$ larval length) were collected exclusively in the fjord region (10-505 larvae per $10 \mathrm{~m}^{2}$ ). The Brunt-Väisälä frequency $\left(\mathrm{N}^{2}\right)$ showed positively significant correlations with anchoveta eggs and larvae abundance, meaning that higher abundance of both eggs and larvae were collected in areas with more stable water columns. This stability may induce higher survival rates of early life stages of anchoveta and may be related with the recent increasing in the landings of other small pelagic fishes such as the Falkland sprat (Sprattus fuegensis).
\end{abstract}

Key words: Ichthyoplankton, stratification, inland sea 


\section{Introduction}

The anchoveta Engraulis ringens Jenyns, 1842 is a small pelagic fish distributed in coastal waters from Peru $\left(4^{\circ} \mathrm{S}\right)$ to southern Chile $\left(42^{\circ} \mathrm{S}\right)$ in the southeast Pacific Ocean. It sustains one of the largest fisheries of the world (Nixon \& Thomas 2001), showing important fluctuations at a multidecadal scale, associated with large-scale changes in ocean temperatures (Chavez et al. 2003). Along central Chile $\left(33^{\circ} \mathrm{S}-40^{\circ} \mathrm{S}\right)$ the spawning activity of these fishes occurs in surface waters from 2 to $80 \mathrm{~km}$ offshore during austral winter, when north winds produce an onshore Ekman layer which advects the early life stages to nearshore waters, away from gelatinous predators (Castro et al. 2000, Hernandez-Miranda et al. 2003, Cubillos et al. 2007). The reproductive event produces large amounts of small spheroid eggs (between 0.10 and $0.44 \mathrm{~mm}^{3}$, Llanos-Rivera \& Castro 2004). From these eggs, after two to three days hatch small larvae from 2.5 to $2.7 \mathrm{~mm}$ larval length which feed endogenously for 50-200 h (Llanos-Rivera \& Castro 2004, 2006). Afterwards, larvae feed exogenously on dinoflagellates and copepods eggs and nauplii, growing at rates of $0.47-0.50 \mathrm{~mm} \mathrm{day}^{-1}$ (Llanos et al. 1996, Hernandez \& Castro 2000, LlanosRivera et al. 2004). On the other hand, there is scarce knowledge on the spatial patterns and dynamics of early stages of anchoveta in their southernmost distribution, particularly in the inland sea of southern Chile.

The fjords zone of Chile is characterized by heavy rainfall (2-5 m year ${ }^{-1}$, Strub et al. 1998) and freshwater input from rivers draining from the Andes which produces an estuarine-type circulation of the coastal ocean, with a sharp halocline at $20 \mathrm{~m}$ depth (Silva et al. 1998, Davila et al. 2002). Chlorophyll- $a$ and primary production show increases in their values during austral spring and autumn seasons (Iriarte et al. 2007). The area is also utilized by several marine fish species as a spawning and nursery zone (Balbontin \& Bernal 1997, 2005, Bernal \& Balbontin 1999, Cordova \& Balbontin 2006, Landaeta \& Castro 2006a, 2006b, Bustos et al. 2007, 2008). Recently, several changes in fish community of southern Chile $\left(42^{\circ}-47^{\circ} \mathrm{S}\right)$ have been detected, including the reduction of biomass of southern hake Merluccius australis and hoki Macruronus magellanicus and the increase of the abundance and landings of pelagic fishes including the Falkland sprat Sprattus fuegensis and anchoveta $E$. ringens (Sernapesca 2006, Aranis et al. 2007). Using available data on oceanographic cruises in the region, we describe the recent presence of large spawning sites and early nursery zones of anchoveta $E$. ringens, associated to stratified zones in fjords of southern Chile. Therefore, the main goal of this work is to show the spatial and temporal variability of the reproductive events and larval distribution of this key pelagic species in southern Chile during the last decade.

\section{Material and methods}

To establish the recent variability (1995-2005) in the abundance and spatial distribution of early life stages of anchoveta in southern Chile, a series of five oceanographic cruises carried out between $41^{\circ} 30^{\prime} \mathrm{S}$ and $47^{\circ} \mathrm{S}$ were analysed (Table 1, Fig. 1). These cruises are part of the CIMAR projects, funded by the Comité Oceanográfico Nacional (CONA) to study the oceanography and marine biodiversity of remote areas of Chile. During the surveys, temperature $\left({ }^{\circ} \mathrm{C}\right)$, salinity and density (units of sigma-t) profiles of the water column were registered employing a Seabird SB-19 CTD (conductivity-temperature-depth profiler). Plankton samples were obtained in all cruises using a standard Bongo net with $0.28 \mathrm{~m}^{2}$ mouth area, 300 $\mu \mathrm{m}$ mesh nets, and two TSK flowmeter placed in the mouth of the nets to estimate the volume filtered. At each station, oblique tows were performed down to $200 \mathrm{~m}$ depth or near the bottom in shallower stations during day and night hours. Towing speed was 2-3 knots. After the completion of each tow, nets were washed and the samples preserved with $5 \%$ formalin buffered with sodium borate.

At laboratory, ichthyoplankton was separated from all samples; eggs and larvae of anchoveta E. ringens were identified using descriptions by Orellana \& Balbontin (1983), and larval stages were categorized as preflexion and postflexion (flexion and postflexion pooled together) according to the bending of the notochord. Standardized abundance was expressed as individuals per $10 \mathrm{~m}^{2}$. Width and length of formalin-preserved anchoveta eggs were measured and the volume was estimated considering the egg an ellipsoid, ( $\mathrm{V}=4 \pi \times a \times b \times c / 3$, where $a, b$ and $c$ are the radii of an ellipse). All measurements were carried out to the nearest $0.01 \mathrm{~mm}$, utilizing a calibrated ocular micrometer fitted to a Nikon stereomicroscope.

\section{Table 1}

\section{Summary of the main characteristics of the surveys carried out}

Resumen de las principales características de los cruceros llevados a cabo

\begin{tabular}{lllc}
\hline Cruise & Survey date & Latitude range & Samples \\
\hline CIMAR 1 & 18 October - 11 November 1995 & $41^{\circ} 30^{\prime}$ ' - 4 4 ${ }^{\circ} \mathrm{S}$ & 89 \\
CIMAR 4-1 & 26 September - 9 October 1998 & $43^{\circ} 30^{\prime} \mathrm{S}-46^{\circ} 30^{\prime} \mathrm{S}$ & 40 \\
CIMAR 4-2 & 25 February - 8 March 1999 & $43^{\circ} 30^{\prime} \mathrm{S}-46^{\circ} 30^{\prime} \mathrm{S}$ & 37 \\
CIMAR 8 & 15 - 28 November 2002 & $43^{\circ} 30^{\prime} \mathrm{S}-46^{\circ} \mathrm{S}$ & 44 \\
CIMAR 11 & 11 - 21 November 2005 & $41^{\circ} 30^{\prime} \mathrm{S}-44^{\circ} \mathrm{S}$ & 37 \\
\hline
\end{tabular}




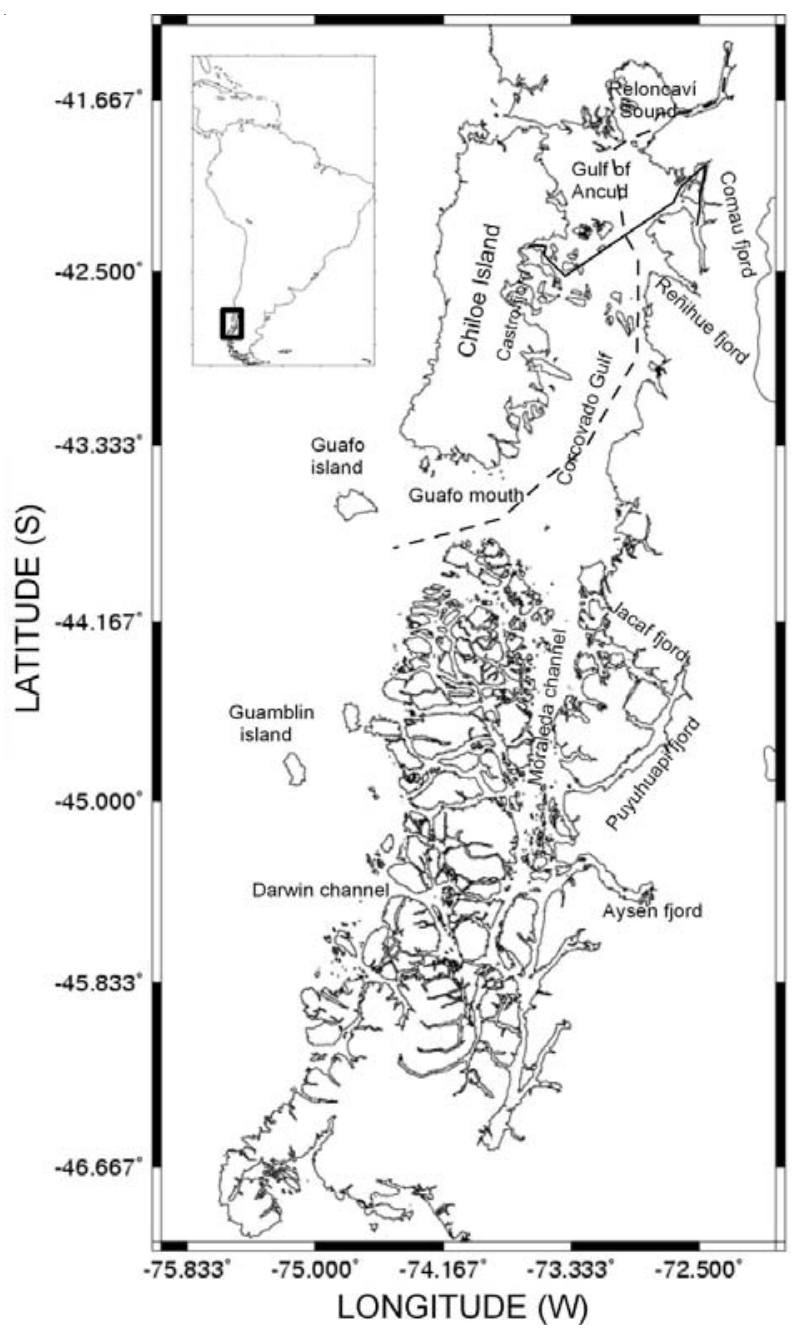

Figure 1

Study area where oceanographic cruises were carried out during 1995-2005. The solid and dotted lines indicate the longitudinal and latitudinal sections showed in Figure 4, respectively

Área de estudio donde se llevaron a cabo los cruceros oceanográficos durante 1995-2005. Las líneas continua y punteada indican las secciones longitudinal y latitudinal mostradas en la Figura 4, respectivamente

To establish if there were significant changes in the abundance of eggs and larvae among cruises (i.e., years), non-parametric tests were run (Mann-Whitney U-test, Mann \& Whitney 1947), using Statistica 6.0 software package.

Latitudinal and longitudinal vertical sections of temperature and salinity were constructed for the November 2005 cruise by using Surfer 8.0 and kriging as interpolation method.
Stratification of the water column during the survey carried out in November 2005 was calculated using the Brunt-Väisälä frequency

$$
\mathrm{N}^{2}=[(\mathrm{g} / \rho) \times(\partial \rho / \partial \mathrm{z})],
$$

where $g=$ gravity $\left(9.8 \mathrm{~m} \mathrm{~s}^{-2}\right)$ and $\rho=$ sea water mean density.

The Brunt-Väisälä frequency $\left(\operatorname{rad~s}^{-1}\right)^{2}$, is the frequency at which a vertically displaced parcel will oscillate within a statically stable environment. To establish potential relationships between the mean value of $\mathrm{N}^{2}$ of the whole water column (log-transformed) and the abundance of early stages of anchoveta in southern Chile, linear regression models by least squares $(y=\alpha+\beta x)$ and Pearson correlations ( $r$ ) (Pearson 1896) were calculated by using the software Statistica 6.0.

\section{Results}

Anchoveta eggs were collected only during two cruises, in October 1995 at only three stations located inside Aysen Fjord (mean \pm SD, $37.9 \pm 12.5$ eggs per $10 \mathrm{~m}^{2}$, not shown), and during November 2005 in the inland sea of Chiloé Island (14,696.9 \pm 47,780.2 eggs per $10 \mathrm{~m}^{2}$, Fig. 2). Larvae were absent during the survey carried out in September-October 1995, and were collected only in one station located in the Guafo Mouth during November 1998 (5.8 larvae per $10 \mathrm{~m}^{2}$, Fig. 2). During February 1999, preflexion larvae were collected along the Moraleda Channel and Corcovado Gulf with a maximum value of 297 individuals per $10 \mathrm{~m}^{2}$ (mean $\pm \mathrm{SD}, 58.4 \pm 85.7$ larvae per $10 \mathrm{~m}^{2}$, Table 2). A mean value of 49.5 larvae per 10 $\mathrm{m}^{2}$ was found during November 2002 and larvae were collected inside the Moraleda Channel and off Darwin

Table 2

Mean larval abundance and range (ind per $10 \mathrm{~m}^{-2}$ ) of anchoveta Engraulis ringens in the fjord region of southern Chile. SD = one standard deviation

Abundancia larval promedio y rango (ind por $10 \mathrm{~m}^{-2}$ ) de anchoveta Engraulis ringens en la región de fiordos del sur de Chile. SD = una desviación estándar

\begin{tabular}{rrrrr}
\hline Year & Mean & SD & \multicolumn{1}{c}{ Min } & \multicolumn{1}{c}{ Max } \\
\hline 1995 & 0 & 0 & 0 & 0 \\
1998 & 5.81 & 0 & 5.81 & 5.81 \\
1999 & 58.36 & 85.66 & 6.25 & 297.56 \\
2002 & 49.48 & 11.55 & 41.32 & 57.65 \\
2005 & 368.44 & 707.69 & 4.3 & 2640.06 \\
\hline
\end{tabular}



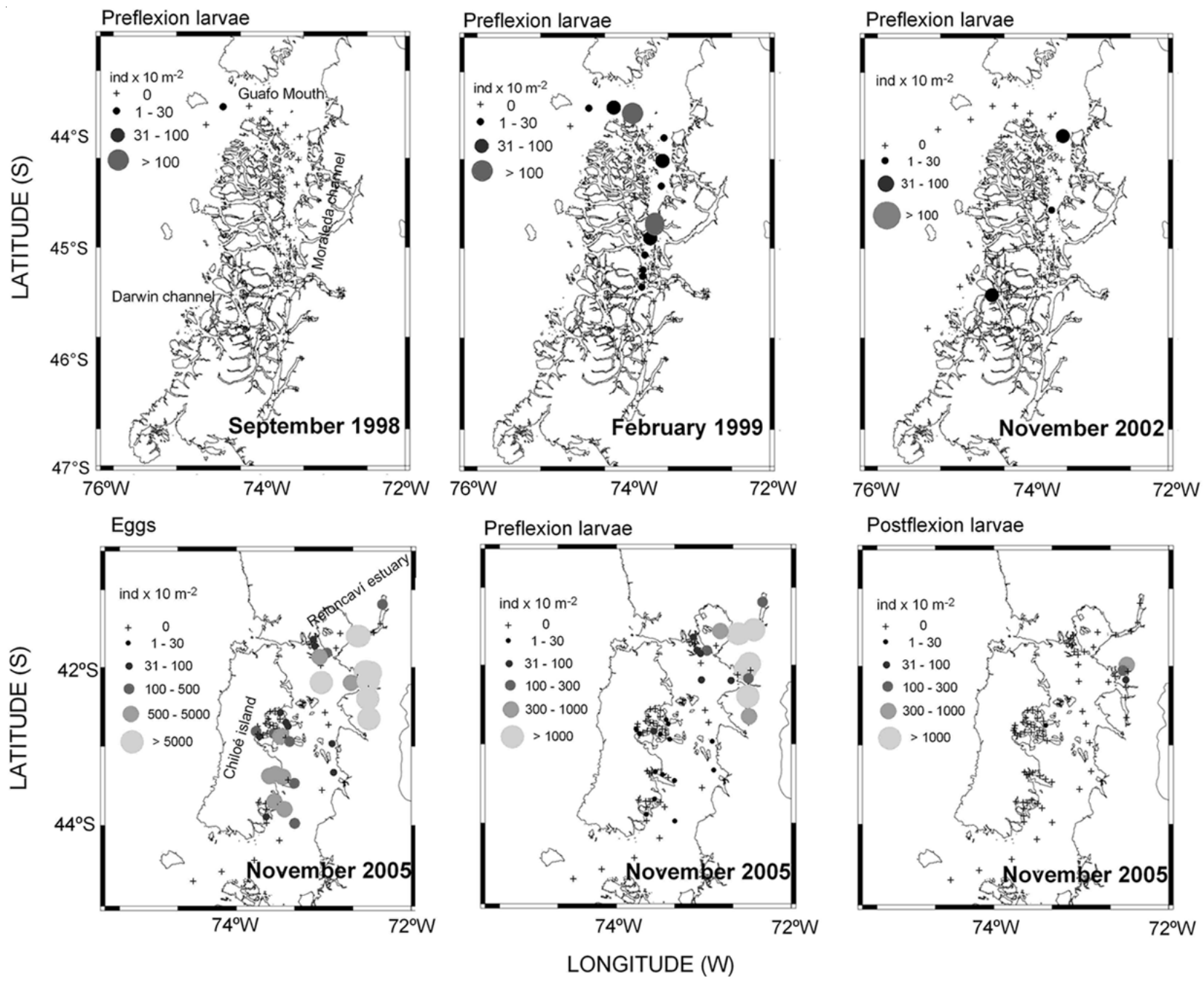

Figure 2

Integrated abundance (ind per $10 \mathrm{~m}^{2}$ ) of eggs, preflexion and postflexion larvae of anchoveta in southern Chile between 1998 and 2005

Abundancia integrada (ind por $10 \mathrm{~m}^{2}$ ) de huevos, larvas en preflexión y postflexión de anchoveta en Chile austral entre 1998 y 2005

Channel (Fig. 3). Compared with the cruise of 1999, a significant increase in the abundance of larvae was found during November 2005 (Mann-Whitney U-test, $\mathrm{U}=2301$, $P<0.001)$.

During November 2005 pre- and postflexion larvae of anchoveta were collected in high abundance in the inland sea of southern Chile (Fig. 2, Table 2). The horizontal distribution of early life stages was aggregated inside fjords of the area (Reloncaví Estuary and Comau Fjord), where horizontal density fronts occurred and vertical stratification was high, because of vertical gradients of temperature (from 14 to $11^{\circ} \mathrm{C}$ in the top 50 $\mathrm{m}$ depth) and salinity (15 to 32 in surface waters) (Fig.
3). On the other hand, the oriental shore of Chiloe Island was well mixed throughout the water column, with a narrow range of temperature $\left(10\right.$ to $11.5^{\circ} \mathrm{C}$, Fig. $\left.3 \mathrm{c}\right)$ and homogeneous values of salinity throughout the water column ( $\sim 32$ units of salinity, Fig. 3d). This area showed scarce abundance of early stages of anchoveta (Fig. 3a, b). The area influenced by oceanic waters at the Guafo Mouth showed a deep entrance of cold $\left(\sim 9^{\circ} \mathrm{C}\right)$ and saltier ( $>33$ ) waters (Fig. 3g, h); however, neither eggs nor larvae of $E$. ringens were collected in that area (Fig. 3e, f).

The abundance of eggs and preflexion larvae was significantly higher inside fjords compared with the nearshore area off Chiloe Island (for eggs: $U=25$, 
Longitudinal transect

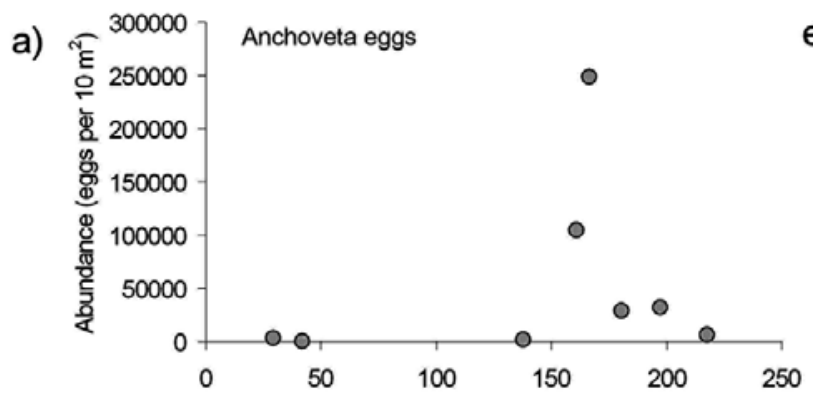

b)

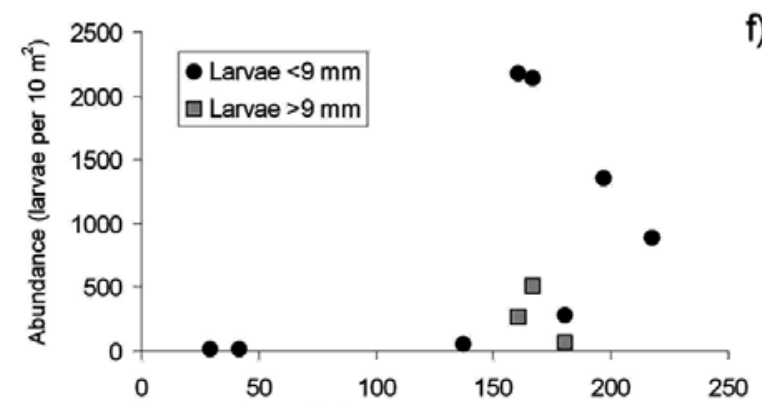

c)

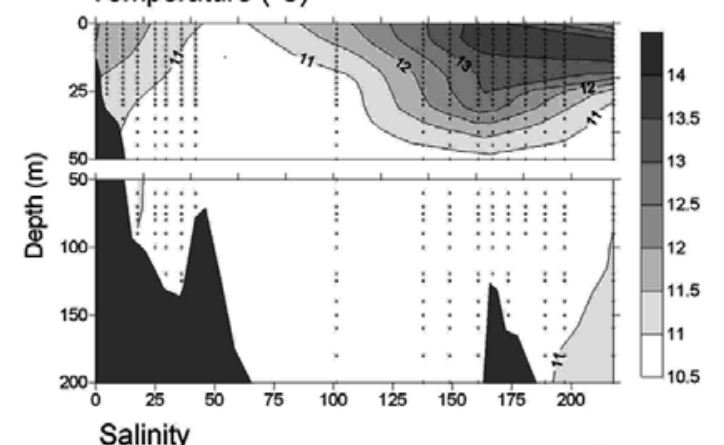

d)

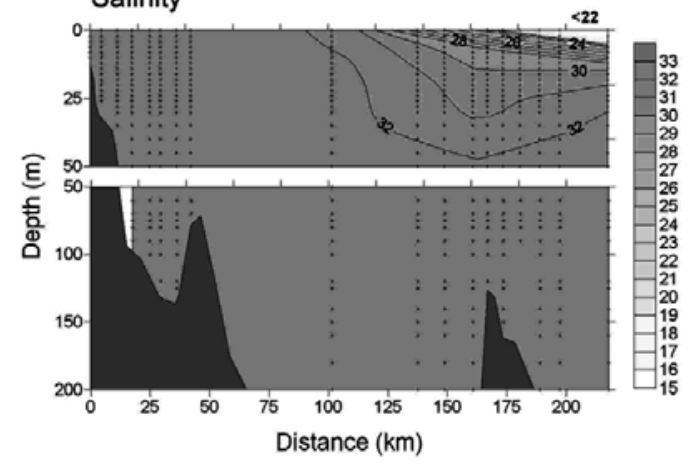

Latitudinal transect

e)

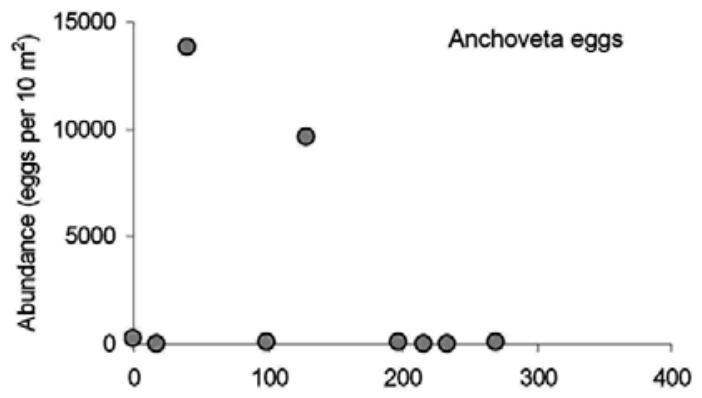

f)

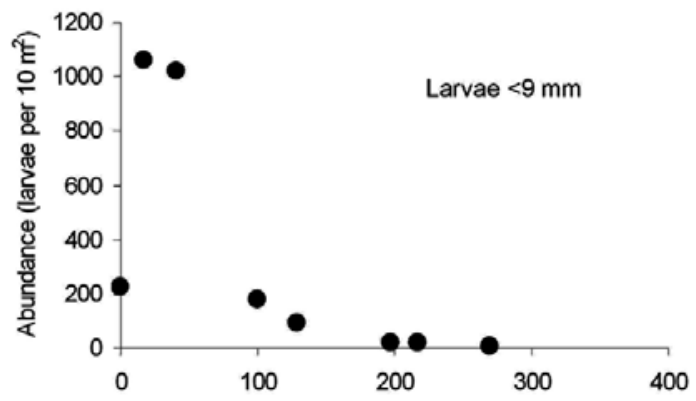

g)

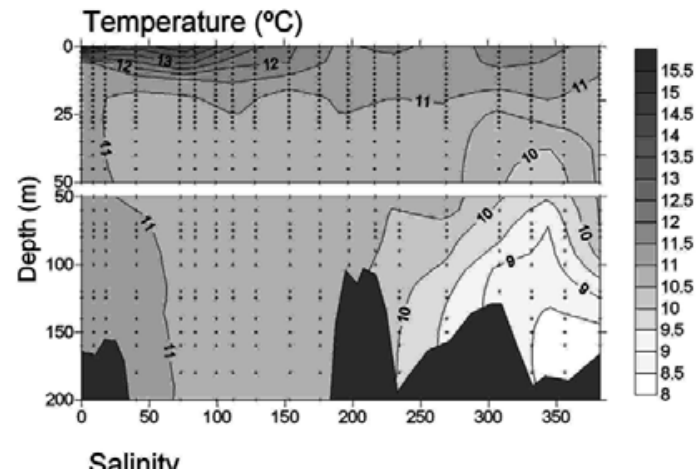

h)

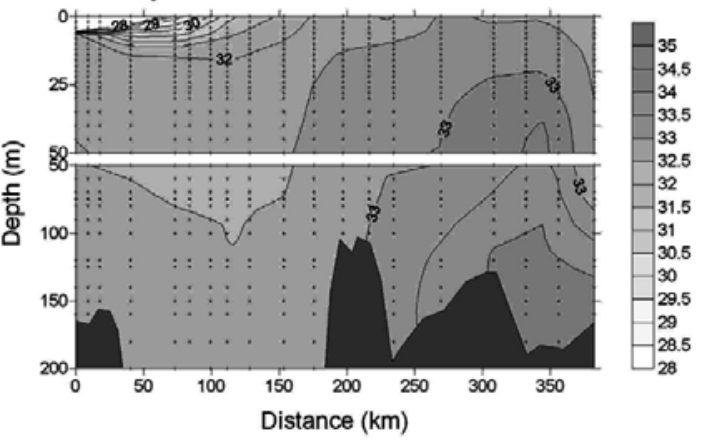

Figure 3

Longitudinal and latitudinal sections from Figure 1 showing a, e) abundance of eggs and b, f) pre- and postflexion larvae (ind. per $\left.10 \mathrm{~m}^{2}\right), \mathrm{c}, \mathrm{g}$ ) temperature $\left({ }^{\circ} \mathrm{C}\right.$ ), and $\mathrm{d}, \mathrm{h}$ ) salinity in the inland sea of southern Chile, during November 2005.

Crosses indicate data from CTD utilized for constructing the vertical sections

Secciones longitunal y latitudinal de la Figura 1, indicando a, e) abundancia de huevos y b, f) larvas en pre y postflexión (ind. por $\left.\left.10 \mathrm{~m}^{2}\right), \mathrm{c}, \mathrm{g}\right)$ temperatura $\left.\left({ }^{\circ} \mathrm{C}\right), \mathrm{y} \mathrm{d}, \mathrm{h}\right)$ salinidad en el mar interior de Chile austral, durante Noviembre de 2005.

Las cruces indican los datos de CTD utilizados en la construcción de las secciones verticales 


\section{Table 3}

Frequency of Brunt-Väisälä $\left(\mathrm{N}^{2}\right)$ range of values and depth of maximum value $(\mathrm{m})$ for different areas surveyed in the inland sea of Chiloe during November 2005

Rango de valores y profundidad de valor máximo (m) de la frecuencia de Brunt-Väisälä $\left(\mathrm{N}^{2}\right)$ para diferentes áreas muestreadas en el mar interior de Chiloé durante noviembre de 2005

\begin{tabular}{llc}
\hline \multicolumn{1}{c}{ Zone } & \multicolumn{1}{c}{$\begin{array}{l}\text { Range } \\
\left(\mathrm{rad} \mathrm{s}^{-1}\right)^{2}\end{array}$} & $\begin{array}{c}\text { Depth of maximum } \\
\text { value }(\mathrm{m})\end{array}$ \\
\hline Reloncaví estuary & $3.54 \times 10^{-8}-6.48$ & 4 \\
Hornopirén - Comau fjord & $4.06 \times 10^{-8}-2.64$ & 6 \\
Dalcahue & $6.03 \times 10^{-9}-1.67 \times 10^{-5}$ & 6 \\
Quellón & $3.64 \times 10^{-8}-2.55 \times 10^{-5}$ & 26 \\
Queilén & $5.93 \times 10^{-9}-3.91 \times 10^{-4}$ & 4 \\
Calbuco & $3.98 \times 10^{-8}-0.0071$ & 6 \\
Castro & $6.06 \times 10^{-9}-2.57 \times 10^{-4}$ & 8 \\
Guafo Mouth & $3.79 \times 10^{-8}-1.6 \times 10^{-4}$ & 24 \\
Gulf of Ancud & $6.32 \times 10^{-9}-0.014$ & 6 \\
\hline
\end{tabular}

\section{Table 4}

Width, length and volume of anchoveta eggs collected at different latitudes along the coast of Chile. SD = standard deviation, $\mathbf{n}=$ number of eggs measured. Modified from Llanos-Rivera \& Castro (2004)

Ancho, longitud y volumen de huevos de anchoveta recolectados en diferentes latitudes a lo largo de la costa de Chile. $\mathrm{SD}=$ desviación estándar, $\mathrm{n}=$ número de huevos medidos. Modificado de Llanos-Rivera \& Castro (2004)

\begin{tabular}{|c|c|c|c|c|c|c|c|}
\hline \multirow[b]{2}{*}{ Latitude and area } & \multicolumn{2}{|c|}{ Width (mm) } & \multicolumn{2}{|c|}{ Length (mm) } & \multicolumn{2}{|c|}{ Volume $\left(\mathrm{mm}^{3}\right)$} & \multirow[b]{2}{*}{$n$} \\
\hline & mean & SD & mean & SD & mean & SD & \\
\hline $20^{\circ}$ Iquique & 0.563 & 0.032 & 1.201 & 0.076 & 0.201 & 0.031 & 1670 \\
\hline $23^{\circ}$ Antofagasta & 0.597 & 0.030 & 1.293 & 0.083 & 0.243 & 0.034 & 425 \\
\hline $33^{\circ}$ Valparaíso & 0.643 & 0.023 & 1.373 & 0.064 & 0.298 & 0.026 & 62 \\
\hline $36^{\circ}$ Talcahuano & 0.657 & 0.027 & 1.377 & 0.063 & 0.312 & 0.030 & 1833 \\
\hline $42^{\circ}$ Puerto Montt & 0.662 & 0.033 & 1.432 & 0.078 & 0.329 & 0.040 & 562 \\
\hline
\end{tabular}

$P<0.001$; for larvae: $U=3, P<0.001)$. Larvae larger than $9 \mathrm{~mm}$ standard length (SL) or postflexion larvae were collected exclusively inside Comau Fjord (Fig. 2) ranging between 10 and 505 larvae per $10 \mathrm{~m}^{2}$.

High heterogeneity of stratification was detected during November 2005 in the inland sea of Chiloe. The highest values of $\mathrm{N}^{2}$ were detected inside fjords such as Reloncavi and Comau Fjords, and off Calbuco (Table 3). The Brunt-Väisälä frequency was lower in coastal areas along the Chiloe Island (Dalcahue, Quellon, Queilen and Castro, Table 3).
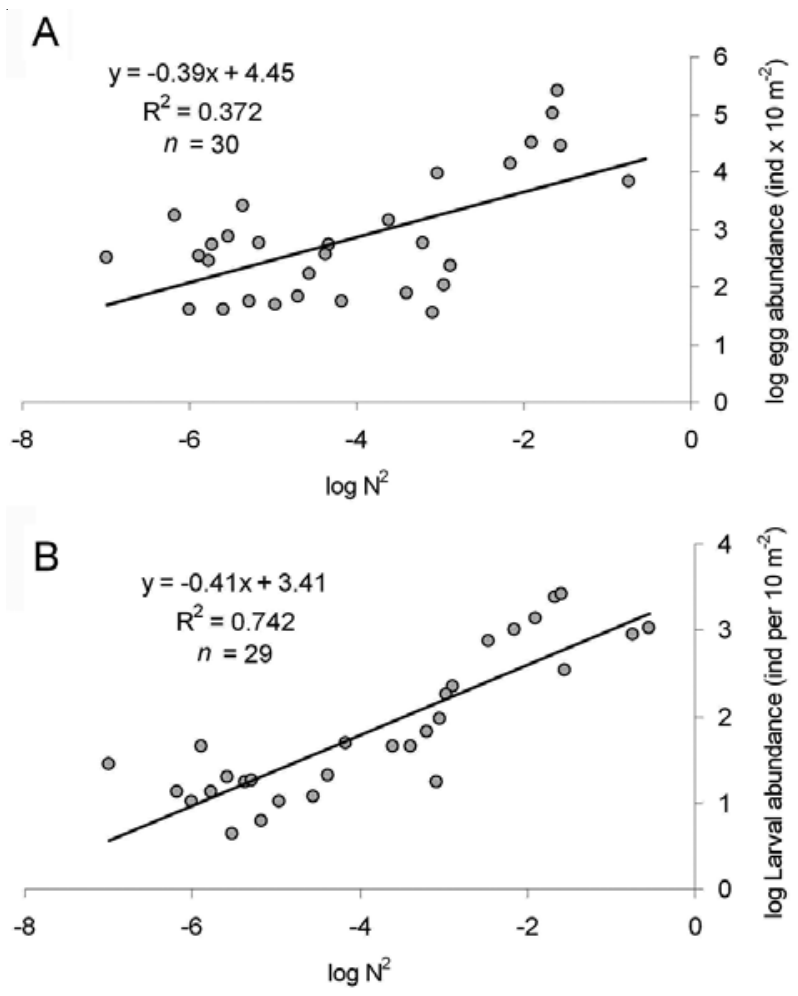

Figure 4

Relationship between log-transformed values of $\mathrm{N}^{2}$ and a) log-transformed abundance of eggs of anchoveta and b) log-transformed abundance of larval anchoveta

Relación entre los valores log-transformados de $\mathrm{N}^{2}$ y a) abundancia log-transformada de huevos de anchoveta y b) abundancia log-transformada de larvas de anchoveta

Log-transformed abundance of eggs of anchoveta were positively associated to log-transformed values of $\mathrm{N}^{2}$ ( $r=0.46, P=0.011$ ), as well as log-transformed abundance of larvae $(r=0.83, P<0.0001)$. This means that in areas showing higher values of vertical stratification, higher abundance of early stages of anchoveta were collected. Least-square simple regression models showed significant relationships among variables (for eggs: $\beta=0.39$, standard error of $\beta=0.096, P<0.001$; for larvae: $\beta=0.41$, standard error of $\beta=0.046, P<0.001$ ) (Fig. 4).

A total of 562 anchoveta eggs were measured from the collections carried out during November 2005. Egg volume ranged between 0.214 and $0.478 \mathrm{~mm}^{3}$, with a mean $( \pm \mathrm{SD})$ of $0.329 \pm 0.040 \mathrm{~mm}^{3}$ (Table 4).

\section{Discussion}

The analysis of the oceanographic cruises carried out between 1995 and 2005 showed the presence of spawning 
and early nursery areas of Engraulis ringens in fjords of southern Chile, associated to zones with highly stratified waters.

Between 1995 and 2005, an increase in the entrance of freshwater to the coastal sea of southern Chile was observed (Davila et al. 2002), strongly decreasing the surface salinity from 32-33 between 1998 and 2001 to 27-28 during 2002 (Iriarte et al. 2007). The reduction of surface salinity increases the vertical stratification of water column, helping to keep algal cells within the photic zone and increasing chlorophyll-a (Gregg et al. 2005). These major environmental changes match with an increase of the landings of anchoveta in southern Chile (Sernapesca 2006), and according to Chavez et al. (2003) correspond to a regime shift from sardine to anchoveta.

An increase in the abundance and/or the increase of the reproductive success of the southern population of Engraulis ringens may explain the presence of the large abundance of eggs and larval anchoveta found recently (i.e., 2005) in the inland sea or fjord zone of southern Chile (Fig. 2, Table 2), previously found in scarce density in the area (e.g., Balbontin \& Bernal 1997). The density of early life stages of E. ringens was similar to those collected in central Chile during austral winter season in the spawning areas off Talcahuano $\left(37^{\circ} \mathrm{S}\right)$ and Valdivia (38 $45^{\circ}$ 'S-39 30'S) (Castro et al. 2000, Cubillos et al. 2007). Also, anchoveta eggs were larger than those from northern and central Chile (Table 4). This result agrees with the latitudinal increase of the egg size of anchoveta found by Llanos-Rivera \& Castro (2004). They hypothesized that the strong latitudinal gradient in egg size of the anchoveta may be an adaptive measure, if different egg sizes are favored at different latitudes or if there is a correlation between egg size and adult life history traits that maximize net reproductive output.

The fjord zone of Chile has also an ocean dynamics quite different from the coastal area of northern and central Chile, where upwelling events dominate the coastal ecosystem and marine organisms have developed several adaptive tactics (Castro et al. 2000, Hernandez \& Castro 2000, Giraldo et al. 2006, Landaeta et al. 2006). In the inland sea of Chile there is a strong seasonality in the phytoplankton abundance, increasing their concentration and the primary productivity during austral spring and autumn (Toro et al. 1999, Iriarte et al. 2007). This seasonality also is observed in the reproduction of several marine fish species, reflected in the different larval fish assemblages detected between austral winter and spring (Cordova \& Balbontin 2006, Landaeta \& Castro 2006a,b). Additionally, the water column has a shallow mixed layer with low surface salinity (<28, Silva et al. 1998) and high stratification (Molinet et al. 2006, Landaeta \& Castro 2006b).
A stratified water column may increase the vertical aggregation of plankters (Heuch 1995, Molinet et al. 2006, 2008), promote feeding success of fish larvae and increase larval growth, reducing mortality rates (Reiss et al. 2002, Landaeta \& Castro 2006b). In the present study, the areas which showed higher vertical stratification were located in the oriental side of the inland sea, where the fjords are the more important topographic feature. Interestingly, the highest abundances of eggs, pre and postflexion larvae of anchoveta were located in the fjord area (Figs. 3, 4, Bustos et al. 2008). On the other hand, the occidental shore of the inland sea showed a well-mixed water column and lower abundances of eggs and larval E. ringens. The tidal wave entering through Guafo Mouth moves to the left (because of Coriolis effect) and northward producing mixing in the shallow waters off Chiloe Island (Caceres et al. 2003). The tidal front may affect the horizontal and vertical distribution of fish larvae (Lough \& Manning 2001) and the turbulence generated by tides and wind effect may produce avoidance of plankton (Pringle 2007), reducing significantly their abundance in the shallower waters along Chiloe island.

Finally, the presence of these spawning and early nursery areas of anchoveta inside fjords in the past years coincides with the finding of dense schools of Falkland sprat (Sprattus fuegensis) in the same area (Aranis et al. 2007), and the reduction of the abundance of demersal fishes, such as southern hake and hoki which previously used the fjord area as spawning grounds (Bustos et al. 2007). Although longer time series of physical data are needed to establish a shift in the environmental variables, the modification of the fish fauna from demersal to small pelagic fishes may be indicative of major changes at ecological scale in southern Chile.

\section{Acknowledgments}

The authors want to thank to three anonymous referees for their comments and suggestions which aided to improve an early version of this manuscript. We also thank MECESUP funding and a CONICYT doctoral scholarship to the first author during the writing of this manuscript. These results are part of the CONA-C11F 05-02 project (CIMAR-FIORDOS 11) adjudicated to FB and CAB. CAB and MFL were partially funded by a FNDR Program from Gobierno Regional de Los Lagos, BIP: 300381910 and Regional Project CONICYT: R04I1003.

\section{Literature cited}

Aranis A, R Meléndez, G Pequeño \& F Cerna. 2007. Sprattus fuegensis en aguas interiores de Chiloé, Chile (Osteichthyes: Clupeiformes: Clupeidae). Gayana 71(1): $102-113$ 
Balbontín F \& R Bernal. 1997. Distribución y abundancia del ictioplancton en la zona austral de Chile. Ciencia y Tecnología del Mar 20: 155-163.

Balbontín F \& R Bernal. 2005. Cambios estacionales en la composición y abundancia del ictioplancton de los canales australes entre el Golfo Corcovado y Golfo Elefantes, Chile. Ciencia y Tecnología del Mar 28(1): 99-111.

Bernal R \& F Balbontín. 1999. Ictioplancton de los fiordos entre el Golfo de Penas y Estrecho de Magallanes y factores ambientales asociados. Ciencia y Tecnología del Mar 22: 143-154.

Bustos CA, F Balbontín \& MF Landaeta. 2007. Spawning of the southern hake Merluccius australis (Pisces: Merluccidae) in Chilean fjords. Fisheries Research 83: 2332.

Bustos CA, MF Landaeta \& F Balbontín. 2008. Efectos ambientales sobre la variabilidad espacial del ictioplancton de Chile austral durante noviembre de 2005. Revista Chilena de Historia Natural 81(2): 205-219.

Cáceres M, A Valle-Levinson \& L Atkinson. 2003. Observations of cross-channel structure of flow in an energetic tidal channel. Journal of Geophysical Research 108(C4): 11.1-11.10.

Castro LR, GR Salinas \& EH Hernández. 2000. Environmental influences on winter spawning of the anchoveta Engraulis ringens off central Chile. Marine Ecology Progress Series 197: 247-258.

Chavez FP, J Ryan, SE Lluch-Cota \& M Ñiquen. 2003. From anchovies to sardines and back: multidecadal change in the Pacific Ocean. Science 299: 217-221.

Córdova G \& F Balbontín. 2006. Distribución espacial de la abundancia y de la talla de ocho tipos de larvas de peces entre la Boca del Guafo y Bahía Anna Pink, zona austral de Chile. Ciencia y Tecnología del Mar 29(1): 153-161.

Cubillos LA, P Ruiz, G Claramunt, S Gacitúa, S Núñez, LR Castro, K Riquelme, C Alarcón, C Oyarzún \& A Sepúlveda. 2007. Spawning, daily egg production, and spawning stock biomasa estimation for common sardine (Strangomera bentincki) and anchovy (Engraulis ringens) off central southern Chile in 2002. Fisheries Research 86: 228-240.

Dávila PM, D Figueroa \& E Müller. 2002. Freshwater input into the coastal ocean and its relation with the salinity distribution off austral Chile $\left(35-55^{\circ} \mathrm{S}\right)$. Continental Shelf Research 22: 521-534.

Giraldo A, R Escribano \& V Marín. 2006. A field test of temperature effects on ecophysiological responses of copepodid Calanus chilensis during coastal upwelling in northern Chile. Continental Shelf Research 26: 1307-1315.

Gregg WW, NW Casey \& CR McClain. 2005. Recent trends in global ocean chlorophyll. Geophysical Research Letters 32: $3606-3610$.
Hernández EH \& LR Castro. 2000. Larval growth of the anchoveta Engraulis ringens during the winter spawning season off central Chile. Fishery Bulletin 98: 704-710.

Hernández-Miranda E, AT Palma \& FP Ojeda. 2003. Larval fish assemblages in nearshore coastal waters off central Chile: temporal and spatial patterns. Estuarine, Coastal and Shelf Science 56: 1075-1092.

Heuch PA. 1995. Experimental evidence for aggregation of salmon louse copepodids (Lepeophtheirus salmonis) in step salinity gradients. Journal of the Marine Biological Association of the United Kingdom 75: 927-939.

Iriarte JL, HE González, KK Liu, C Rivas \& C Valenzuela. 2007. Spatial and temporal variability of chlorophyll and primary productivity in surface waters of southern Chile (41.5-43 ${ }^{\circ}$ S). Estuarine, Coastal and Shelf Science 74: 471480 .

Landaeta MF \& LR Castro. 2006a. Variabilidad estacional en los patrones espaciales de las asociaciones ictioplanctónicas de la zona de fiordos de Chile austral. Ciencia y Tecnología del Mar 29(2): 25-44.

Landaeta MF \& LR Castro. 2006b. Larval distribution and growth of the rockfish, Sebastes capensis (Sebastidae, Pisces), in the fjords of southern Chile. ICES Journal of Marine Science 63: 714-724.

Landaeta MF, GA Herrera, M Pedraza, CA Bustos \& LR Castro. 2006. Reproductive tactics and larval development of bigeye flounder, Hippoglossina macrops, off central Chile. Journal of the Marine Biological Association of the United Kingdom 86: 1253-1264.

Llanos A, G Herrera \& P Bernal. 1996. Análisis del tamaño de las presas en la dieta de las larvas de cuatro clupeiformes en un área costera de Chile central. Scientia Marina 60: 435-442.

Llanos-Rivera A \& LR Castro. 2004. Latitudinal and seasonal egg-size variation of the anchoveta (Engraulis ringens) off the Chilean coast. Fishery Bulletin 102: 207-212.

Llanos-Rivera A \& LR Castro. 2006. Inter-population differences in temperature effects on Engraulis ringens yolk-sac larvae. Marine Ecology Progress Series 312: 245253.

Llanos-Rivera A, G Herrera \& P Bernal. 2004. Food selective and diet overlap in larvae of Clupeiform species from central Chile. Cahiers de Biologie Marine 45: 1-8.

Lough RG \& JP Manning. 2001. Tidal-front entrainment and retention of fish larvae on the southern flank of Georges Bank. Deep-Sea Research II 48: 631-644.

Mann HB \& DR Whitney. 1947. On a test of whether one of two random variables is stochastically larger than the other. The Annals of Mathematical Statistics 18: 50-60.

Molinet C, A Valle-Levinson, CA Moreno, M Cáceres, M Bello \& M Castillo. 2006. Effect of sill processes on the distribution of epineustonic competent larvae in a stratified 
system of Southern Chile. Marine Ecology Progress Series 324: 95-104.

Molinet C, E Niklitschek, CA Moreno \& A Arévalo. 2008. Vertical distribution of early and competent larvae of Concholepas concholepas in two systems of Chilean inland seas. Marine Biology 153(5): 779-788.

Nixon S \& A Thomas. 2001. On the size of Peru upwelling ecosystem. Deep Sea Research I 48: 2521-2528.

Orellana MC \& F Balbontín. 1983. Estudio comparativo de las larvas de clupeiformes de la costa de Chile. Revista de Biología Marina 19: 1-46.

Pearson K. 1896. Mathematical contributions to the theory of evolution. III. Regression, Heredity and Panmixia. Philosophical Transactions of the Royal Society of London. Series A 187: 253-318.

Pringle JM. 2007. Turbulence avoidance and the wind-driven transport of plankton in the surface Ekman layer. Continental Shelf Research 27: 670-678.

Reiss C, A Anis, C Taggart, J Dower \& B Ruddick. 2002. Relationship among vertically structured in situ measures of turbulence, larval fish, their feeding success, and copepods on Western Bank, Scotian Shelf. Fisheries Oceanography 11: 156-174.

Sernapesca. 2006. Anuario Estadístico de Pesca 2005. Sernapesca, Valparaíso. Ministerio de Economía, Fomento y Reconstrucción. República de Chile. 140 pp.

Silva N, C Calvete \& H Sievers. 1998. Masas de agua y circulación general para algunos canales australes entre Puerto Montt y Laguna San Rafael, Chile (Crucero CimarFiordo 1). Ciencia y Tecnología del Mar 21: 17-48.

Strub PT, JM Mesías, V Montecino, J Rutllant \& S Salinas. 1998. Coastal ocean circulation off western South America. In: Robinson AR \& KH Brink (eds). The Sea 11: 273-313. John Wiley \& Sons, New York.

Toro JE, PI Paredes, DJ Villagra \& CM Senn. 1999. Seasonal variation in the phytoplanktonic community, seston and environmental variables during a 2-year period and oyster growth at two mariculture sites, southern Chile. Marine Ecology 20: 63-89.

Recibido el 27 de marzo de 2008 y aceptado el 10 de junio de 2008 